\title{
The effect of rubber mats on lesions and lameness in gillts housed in gestation stalls
}

\author{
M. Ostović, S. Menčik*, A. Ekert Kabalin, D. Matičić, T. Trbojević \\ Vukičević, K. Matković, I. Sabolek, D. Potočnjak and Ž. Pavičić
}

\section{Abstract}

Rubber mats have not yet been widely established in pig production. However, studies mostly focusing on lesions, lameness and behaviours of lactating and group-housed pregnant sows have reported favourable results. To the best of our knowledge, lesions and lameness in sows or gilts housed individually in rubber floor gestation stalls have not been previously investigated. This study was carried out on a commercial pigbreeding farm service unit during a 28-day production cycle in all seasons. Twentyeight gilts were divided into two equal groups, control and experimental groups, and observed for each cycle. The control group was housed in standard gestation stalls with concrete slatted floor, which in the experimental group was covered with an adjusted rubber mat. During each cycle, lesions were scored on days 1, 8, 15 and 28, and lameness on day 1 and upon gilt transfer from the service unit on day 29. Gilts in rubber floor stalls showed significant reduction $(P<0.05)$ in lesions during the cooler period. Conversely, mats had no impact on lameness score in any season. No significant correlations were found between lesions and the percentage of gilts with a particular lameness score. Accordingly, rubber flooring may improve the welfare of gilts in gestation stalls through lower lesion incidence; however, ambient temperature should be taken into consideration when available.

Key words: pigs; rubber mat; flooring; lesions; lameness; animal welfare

\section{Introduction}

Numerous studies have been conducted worldwide on the effect of flooring on pig health and welfare. The slatted floors most commonly used in

sow housing are considered one of the main reasons for the need for culling due to lameness (Dewey, 2006; Heinonen et al., 2013; Cador et al., 2014). Kilbride et al.

Mario OSTOVIĆ, DVM, PhD, Associate Professor, Sven MENČIK*, DVM, PhD, Assistant Professor (Corresponding author, e-mail: smencik@vef.hr), Anamaria EKERT KABALIN, DVM, PhD, Full Professor, Dražen MATICIĆ, DVM, PhD, Academician, Tajana TRBOJEVIĆ VUKIČEVIĆ, DVM, PhD, Full Professor, Kristina MATKOVIĆ, DVM, PhD, Full Professor, Ivana SABOLEK, DVM, Assistant, Dalibor POTOČNJAK, DVM, PhD, Full Professor, Željko PAVIČIĆ, DVM, PhD, Full Professor, Faculty of Veterinary Medicine, University of Zagreb, Zagreb, Croatia 
(2009) reported that the risk of lameness was greater in pregnant sows housed on slatted floors than in sows housed on solid concrete floors with straw bedding or those housed outdoors on soil. Heinonen et al. (2006) also found that sows and gilts housed on slatted floors had twice the odds of being lame, and 3.7 times the odds of being severely lame than those housed on solid floors. The risk of lameness in pregnant sows increases with the presence of claw infections and claw lesions (Gjein and Larssen, 1995; Cador et al., 2014), which are good indicators of poor welfare due to inadequate flooring (EFSA, 2007).

Various floor types exert different effects on claw lesions, whereby the frequency of lesions in pigs is almost twice as high on slatted than on solid floors (Dewey, 2006). The risk of leg or claw lesions in pigs kept on slatted floor varies with slat and gap width relative to claw size and with the material used for floor manufacture (EFSA, 2005). Considering floor material, concrete floors are most frequently used in animal housing (Kymäläinen et al., 2009; Maes et al., 2016). Concrete is fairly durable and resistant to wear, acceptable for maintaining appropriate hygienic conditions and relatively inexpensive. However, the hardness, abrasiveness and slipperiness of concrete floors cause leg and claw lesions, thus resulting in animal lameness (Telezhenko et al., 2007). This causes not only animal welfare problems but also economic losses to pig producers (Pluym et al., 2011; Nalon et al., 2013; van Riet et al., 2019). Concrete floors represent a major risk for claw lesions in young gilts (Kornegay et al., 1990).

Rubber mats have become a popular tool for improving flooring conditions in dairy production (Rushen et al., 2008), but have not yet been established in pig production. Studies have mainly focused on lactating (Gravås, 1979; Boyle et al., 2000; Farmer et al., 2006; Zurbrigg, 2006;
Devillers and Farmer, 2008) and grouphoused pregnant sows (Tuyttens et al., 2008; Elmore et al., 2010; Calderón Díaz et al., 2013; Calderón Díaz and Boyle, 2014; Bos et al., 2016) and have shown the welfare benefits of rubber mats in pigs.

According to Council Directive 2008/120/EC, in the European Union sows and gilts may be kept individually for the first four weeks following service. For the gilts, this is their first experience of individual and tight housing. Therefore, the aim of the study was to assess whether rubber flooring in the service unit influenced their welfare, based on the incidence of lesions and lameness.

\section{Materials and methods}

\section{Animals, husbandry and experimental design}

The study was performed in commercial production conditions, at a pig farm service unit. Production cycles were observed in all seasons according to the availability of gilts, as follows: May-June (spring), September (summer), November (autumn) and DecemberJanuary (winter). Each of the four production cycles lasted for 28 days.

Two groups of gilts of the Large White breed, control and experimental groups (14 gilts each) were observed per cycle, for a total of 112 animals. Control group gilts were housed in $1.80 \times 0.60 \mathrm{~m}$ gestation stalls with a concrete slatted floor, 80$\mathrm{mm}$ slat and 20-mm gap width. In the stalls holding experimental group gilts, the stall floor was additionally covered with $2-\mathrm{cm}$ thick textured rubber mat (Gumiimpex-GRP Inc., Croatia), adjusted to the stall size and floor gaps.

On the farm, gilts are fed with concentrated feed twice a day from the same troughs used for water supply ad libitum. The housing has natural and at least 8-hour artificial illumination and forced ventilation. During the cold season, there is no heating, but acceptable 
microclimate conditions are achieved by ventilation conditioning.

For additional information on the gilts, husbandry conditions and experimental design, including air temperature measurement in the service unit, see the studies by Pavičić et al. (2014) and Ostović et al. (2015).

\section{Lesion and lameness scoring}

Gilts were scored for lesions at the time of their entry into stalls (day 1), and then on days 8, 15 and 28 of each cycle. Lesions were assessed by the same trained observer using a scoring system adopted from Elmore et al. (2010) and modified for this study by assessing five body regions ( $\mathrm{A}$ - head, neck and shoulders, B - mid-body and udder, C rump, tail, anus and vulva, D - forelegs and claws, E - hindlegs and claws) and using a 0-3 scoring scale, whereby "no blemishes" previously included in score 1 were singled out as score 0 . If differently scored lesions were found in the same part of the body, the higher score was taken in consideration. The highest total lesion score (TLS) was 15.

As the lameness score includes gilt stride, lameness scoring was performed at the time of their accommodation in stalls (day 1), and then on their transfer from the service unit (day 29). Lameness was scored by the same trained observer using a previously described 0-5 scoring system (Main et al., 2000; Estienne et al., 2006; Elmore et al., 2010).

\section{Statistical analysis}

STATISTICA v. 13.5 (TIBCO Software Inc., 2019) was used on statistical data processing. All study parameters were processed by the usual descriptive statistics. Results related to lesions were expressed as median, minimal and maximal value (min-max) and those on lameness as percentage (\%) of gilts with a particular lameness score. Statistical significance of differences between the control and experimental group was tested by Mann-Whitney $U$-test (lesions) and $\chi^{2}$-test (lameness). Statistical significance of differences in total lesions between scoring days according to production cycles/seasons within each group was tested by Freedman ANOVA and the Kendall Coefficient of Concordance. Statistical significance of differences in the proportion of animals with a particular grade of lameness between scoring days according to production cycles/seasons within each group was tested by the $\chi^{2}$ test. The level of statistical significance was set at $P<0.05$. Correlation between lesions and proportion of gilts with a particular lameness score was assessed by Spearman Rank Order Correlations.

\section{Results and discussion}

Study results are shown in Tables 1-3. As presented in Table 1, the highest TLS was determined on the production cycle day 1 in both groups of gilts during all seasons. Compared to days 1 and 8, TLS median was significantly lower $(P<0.05)$ on cycle days 15 and 28 in spring and autumn. This finding could be explained by the several-fold greater TLS at initial gilt transfer to stalls, which could be associated with air temperature and gilt fighting (Choi et al., 2011). At moderate spring and autumn temperatures, gilts were more aggressive, which resulted in a higher rate of lesions on transportation and accommodation in the area intended for sows after weaning, where gilts were placed before entering the service unit. Air temperature in the service unit on cycle day 1 was $18.6^{\circ} \mathrm{C}$ in spring, $23.2^{\circ} \mathrm{C}$ in summer, $17.5^{\circ} \mathrm{C}$ in autumn and $17.4^{\circ} \mathrm{C}$ in winter (Pavičić et al., 2014; Ostović et al., 2015); however, seasonal variations in air temperature on transportation outside the housing unit were even greater. In summer and winter, i.e. at higher and lower air temperature, the gilts were less aggressive, which 
resulted in a lower lesion score on day 1 of their accommodation in stalls. TLS did not differ significantly between days observed in the summer and winter production cycles. Anil et al. (2005; 2006) reported a significantly higher TLS in stall-housed sows during late gestation compared to earlier stages, explaining this finding by the increasing body weight and consequent reduction in space available with advancing gestation. The non-significant differences in TLS during summer and winter in the present study could be ascribed to the fact that this described space reduction was less pronounced by cycle day 28 . In addition, the size of gilts is smaller compared to sows (McGlone et al., 2004; O'Connell et al., 2007). However, gilts in rubber floor stalls had a significantly lower $(P<0.05)$ TLS on cycle day 28 in autumn and winter.

According to lesion localization, the difference between the control and experimental groups was found in foreleg and claw lesions, indicating that these lesions contribute significantly to TLS in gilts. The average foreleg and claw lesion score in gilts during the winter production cycle and on day 28 of the autumn production cycle was significantly lower $(P<0.05)$ in the experimental group. A significantly higher $(P<0.05)$ lesion score in the experimental group was only determined on day 8 of spring cycle for the head, neck and shoulder region.

Spatial restriction and reduced mobility can result in inadequate comfort in individually housed sows, manifesting as restlessness and frequent posture changes (Ostović et al., 2012). In addition, the type of stall floor can also influence the frequency of posture changing (Pavičić et al., 2006), whereby inappropriate slip resistance and flooring surface friction may exert unfavourable effects on sow posture changes and consequentially cause injuries (Barnett et al., 2001; Bergeron et al., 2008). The rate of lesions in this study was found to be reduced considerably in gilts accommodated on the rubber floor during the cooler period (Table 1). It could be ascribed to better physical gilt comfort offered by this type of flooring on posture change and lying down, longer period of resting

Table 1. Total lesion score for gilts housed in concrete and rubber floor gestation stalls.

\begin{tabular}{|c|c|c|c|c|c|c|}
\hline \multirow{3}{*}{ Season } & \multirow{3}{*}{ Flooring } & \multicolumn{4}{|c|}{ Production cycle } & \multirow{3}{*}{ Average } \\
\hline & & Day 1 & Day 8 & Day15 & Day 28 & \\
\hline & & \multicolumn{4}{|c|}{ Score } & \\
\hline \multirow{2}{*}{ Spring } & Concrete & $4(2-7)^{a}$ & $3(2-4)^{b}$ & $1(0-3)^{c}$ & $1(1-3)^{c}$ & $2(0-7)$ \\
\hline & Rubber & $4(2-7)^{a}$ & $3(2-4)^{a}$ & $1(0-3)^{b}$ & $1(0-2)^{b}$ & $2(0-7)$ \\
\hline \multirow{2}{*}{ Summer } & Concrete & $0.5(0-4)$ & $0.5(0-2)$ & $1(0-3)$ & $1(0-2)$ & $1(0-4)$ \\
\hline & Rubber & $0(0-6)$ & $0(0-3)$ & $0(0-2)$ & $0.5(0-2)$ & $0(0-6)$ \\
\hline \multirow{2}{*}{ Autumn } & Concrete & $5(4-6)^{a}$ & $2(2-4)^{b}$ & $0(0-1)^{c}$ & $1(0-4)^{c, *}$ & $2(0-6)$ \\
\hline & Rubber & $5(3-6)^{a}$ & $2(2-2)^{b}$ & $0(0-1)^{c}$ & $0(0-1) c *$ & $1.5(0-6)$ \\
\hline \multirow{2}{*}{ Winter } & Concrete & $1(0-3)$ & $0(0-2)$ & $0.5(0-2)$ & $1(0-2)^{*}$ & $1(0-3)$ \\
\hline & Rubber & $1(0-2)$ & $0(0-1)$ & $0(0-1)$ & $0(0-1)^{*}$ & $0(0-2)$ \\
\hline
\end{tabular}

$n=14$ gilts per group and season; values are expressed as median (min-max); ${ }^{\mathrm{a}, \mathrm{b}, \mathrm{c}}$ values in the same row marked by different letter differed significantly $(P<0.05)$; ${ }^{*}$ values between groups in the same season differed $(P<0.05)$. 
(Pavičić et al., 2014; Ostović et al., 2015), and to improved thermal comfort at lower ambient temperature (Boyle et al., 2000; Zurbrigg, 2006; Tuyttens et al., 2008; Elmore et al., 2010). The mean air temperature in the service unit during particular production cycles was $20.4{ }^{\circ} \mathrm{C}$ (spring), $22{ }^{\circ} \mathrm{C}$ (summer), $16.5{ }^{\circ} \mathrm{C}$ (autumn) and $16.3{ }^{\circ} \mathrm{C}$ (winter), with the lowest temperatures recorded on the $28^{\text {th }}$ day of the autumn $\left(15.5^{\circ} \mathrm{C}\right)$ and winter $\left(15^{\circ} \mathrm{C}\right)$ cycles (Pavičić et al., 2014; Ostović et al., 2015).

As shown in Table 2, the highest recorded lameness score 2 (lameness detected) was determined in two control gilts on their transfer from the service unit (day 29), i.e. one gilt each in the summer and autumn production cycles.
However, no significant difference was found between the control and experimental group in any production cycle. The percentage of gilts with a particular lameness score between day 1 and day 29 differed significantly $(P<0.05)$ during the summer and autumn cycle in the control group, and during the spring and winter cycle in the experimental group. In both groups, there were no significant correlations between lesion score and the percentage of gilts with a particular lameness score (Table 3). Elmore et al. (2010) also found no differences in lameness scores between the groups of sows housed in pens with rubber and concrete solid floor feeding stalls; however, the animals were observed for only 10 days. On the other

Table 2. Proportion of gilts with particular lameness score housed in concrete and rubber floor gestation stalls.

\begin{tabular}{|c|c|c|c|c|c|c|c|c|}
\hline \multirow{3}{*}{\multicolumn{2}{|c|}{ Production cycle }} & \multicolumn{6}{|c|}{ Gilts (\%) } & \multirow{4}{*}{$P$-value } \\
\hline & & \multicolumn{3}{|c|}{ Concrete flooring } & \multicolumn{3}{|c|}{ Rubber flooring } & \\
\hline & & \multicolumn{6}{|c|}{ Score } & \\
\hline Season & Day & 0 & 1 & 2 & 0 & 1 & 2 & \\
\hline \multirow{2}{*}{ Spring ${ }^{a}$} & 1 & 78.6 & 21.4 & - & 71.4 & 28.6 & - & $>0.05$ \\
\hline & 29 & 71.4 & 28.6 & - & 85.7 & 14.3 & - & $>0.05$ \\
\hline \multirow{2}{*}{ Summer ${ }^{b}$} & 1 & 71.4 & 28.6 & - & 78.6 & 21.4 & - & $>0.05$ \\
\hline & 29 & 71.4 & 21.4 & 7.2 & 85.7 & 14.3 & - & $>0.05$ \\
\hline \multirow{2}{*}{ Autumn ${ }^{b}$} & 1 & 92.9 & 7.1 & - & 78.6 & 21.4 & - & $>0.05$ \\
\hline & 29 & 78.6 & 14.3 & 7.1 & 85.7 & 14.3 & - & $>0.05$ \\
\hline \multirow{2}{*}{ Winter ${ }^{a}$} & 1 & 85.7 & 14.3 & - & 85.7 & 14.3 & - & $>0.05$ \\
\hline & 29 & 78.6 & 21.4 & - & 92.9 & 7.1 & - & $>0.05$ \\
\hline
\end{tabular}

$n=14$ gilts per group and season; a values between day 1 and day 29 for rubber flooring differed significantly $(P<0.05)$; ${ }^{\mathrm{b}}$ values between day 1 and day 29 for concrete flooring differed significantly $(P<0.05)$.

Table 3. Correlation between lesion score and percentage of gilts with particular lameness score.

\begin{tabular}{c|c|c|c|c|}
\hline \multirow{2}{*}{$\begin{array}{c}\text { Concrete flooring } \\
\text { Rubber flooring }\end{array}$} & Spring & Summer & Autumn & Winter \\
\cline { 2 - 5 } & \multicolumn{4}{|c|}{ Lameness score (\%) } \\
\hline \multirow{2}{*}{ Lesion score } & -0.096 & -0.075 & -0.206 & 0.312 \\
\hline
\end{tabular}


hand, Calderón Díaz et al. (2013) found that sows housed on rubber slat mats had a reduced risk of lameness compared to those on concrete slatted floor throughout pregnancy, indicating that pregnant sows should be observed for a longer period of time to assess the effect of rubber flooring on lameness reliably.

\section{Conclusions}

In conclusion, rubber flooring may improve the welfare of individually housed gilts by reducing the rate of lesions, which was recorded during the cold season, suggesting that environmental temperature should be a consideration in deciding when to use this type of flooring.

\section{References}

1. ANIL, L., S. S. ANIL, J. DEEN and S. K. BAIDOO (2006): Cortisol, behavioral responses, and injury scores of sows housed in gestation stalls. J. Swine Health Prod. 14, 196-201.

2. ANIL, L., S. S. ANIL, J. DEEN, S. K. BAIDOO and J. E. WHEATON (2005): Evaluation of well-being, productivity, and longevity of pregnant sows housed in groups in pens with an electronic sow feeder or separately in gestation stalls. Am. J. Vet. Res. 66, 1630-1638.

3. BARNETT, J. L., P. H. HEMSWORTH, G. M. CRONIN, E. C. JONGMAN and G. D. HUTSON (2001): A review of the welfare issues for sows and piglets in relation to housing. Aust. J. Agr. Res. 52, 1-28.

4. BERGERON, R., M.-C. MEUNIER-SALAÜN and S. ROBERT (2008): The welfare of pregnant and lactating sows. In: Faucitano, L., A. L. Schaefer: Welfare of pigs: from birth to slaughter. Wageningen, Netherlands \& Versailles, France: Wageningen Academic Publishers \& Éditions Quæ (65-95).

5. BOS, E. J., M. M. J. VAN RIET, D. MAES, S. MILLET, B. AMPE, G. P. JANSSENS and F. A. TUYTTENS (2016): Effect of rubber flooring on group-housed sows' gait and claw and skin lesions. J. Anim. Sci. 94, 2086-2096.

6. BOYLE, L. A., D. REGAN, F. C. LEONARD, P. B. LYNCH and P. BROPHY (2000): The effect of mats on the welfare of sows and piglets in the farrowing house. Anim. Welf. 9, 39-48.

7. CADOR, C., F. POL, M. HAMONIAUX, V. DORENLOR, E. EVENO, C. GUYOMARC'H and N. ROSE (2014): Risk factors associated with leg disorders of gestating sows in different grouphousing systems: a cross-sectional study in 108 farrow-to-finish farms in France. Prev. Vet. Med. 116, 102-110.

8. CALDERÓN DÍAZ, J. A., A. G. FAHEY, A. L. KILBRIDE, L. E. GREEN and L. A. BOYLE (2013): Longitudinal study of the effect of rubber slat mats on locomotory ability, body, limb and claw lesions, and dirtiness of group housed sows. J. Anim. Sci. 91, 3940-3954.

9. CALDERÓN DÍAZ, J. A. and L. A. BOYLE (2014): Effect of rubber slat mats on the behaviour and welfare of group housed pregnant sows. Appl. Anim. Behav. Sci. 151, 13-23.

10. CHOI, H. L., S. H. HAN, L. D. ALBRIGHT and W. K. CHANG (2011): The correlation between thermal and noxious gas environments, pig productivity and behavioral responses of growing pigs. Int. J. Environ. Res. Public Health 8, 3514-3527.

11. Council Directive 2008/120/EC of 18 December 2008 laying down minimum standards for the protection of pigs (Codified version). O. J. L 47/5.

12. DEVILLERS, N. and C. FARMER (2008): Effects of a new housing system and temperature on sow behaviour during lactation. Acta Agr. Scand. A-An. 58, 55-60.

13. DEWEY, C. E. (2006): Diseases of the nervous and locomotor systems. In: Straw, B. E., J. J. Zimmerman, S. D'Allaire, D. J. Taylor: Diseases of swine. Ames, Iowa: Blackwell Publishing (87-112).

14. (EFSA) European Food Safety Authority (2005): The welfare of weaners and rearing pigs: effects of different space allowances and floor types. Scientific Report, EFSA-Q-2004-077. EFSA - AHAW Panel (Animal Health and Welfare). Annex to the EFSA J. 268, 1-19.

15. (EFSA) European Food Safety Authority (2007): Animal health and welfare aspects of different housing and husbandry systems for adult breeding boars, pregnant, farrowing sows and unweaned piglets. Scientific Report, EFSA-Q-2006-028. EFSA AHAW Panel (Animal Health and Welfare). Annex to the EFSA J. 572, 1-13.

16. ELMORE, M. R. P., J. P. GARNER, A. K. JOHNSON, B. T. RICHERT and E. A. PAJOR (2010): A flooring comparison: the impact of rubber mats on the health, behaviour, and welfare of group-housed sows at breeding. Appl. Anim. Behav. Sci. 123, 7-15.

17. ESTIENNE, M. J., A. F. HARPER and J. W. KNIGHT (2006): Reproductive traits in gilts housed individually or in groups during the first thirty days of gestation. J. Swine Health Prod. 14, 241-246.

18. FARMER, C., N. DEVILLERS, T. WIDOWSKI and D. MASSÉ (2006): Impacts of a modified farrowing pen design on sow and litter performances and air quality during two seasons. Livest. Sci. 104, 303-312.

19. GJEIN, H. and R. B. LARSSEN (1995): The effect of claw lesions and claw infections on lameness in loose housing of pregnant sows. Acta Vet. Scand. $36,451-459$. 
20. GRAVÅS, L. (1979): Behavioural and physical effects of flooring on piglets and sows. Appl. Anim. Ethol. 5, 333-345.

21. HEINONEN, M., J. ORAVAINEN, T. ORRO, L. SEPPÄ-LASSILA, E. ALA-KURIKKA, J. VIROLAINEN, A. TAST and O. A. T. PELTONIEMI (2006): Lameness and fertility of sows and gilts in randomly selected loose-housed herds in Finland. Vet. Rec. 159, 383-387.

22. HEINONEN, M., O. PELTONIEMI and A. VALROS (2013): Impact of lameness and claw lesions in sows on welfare, health and production. Livest. Sci. 156, 2-9.

23. KILBRIDE, A. L., C. E. GILLMAN and L. E. GREEN (2009): A cross-sectional study of the prevalence of lameness in finishing pigs, gilts and pregnant sows and associations with limb lesions and floor types on commercial farms in England. Anim. Welf. 18, 215-224.

24. KORNEGAY, E. T., K. L. BRYANT and D. R. NOTTER (1990): Toe lesion development in gilts and sows housed in confinement as influenced by toe size and toe location. Appl. Agr. Res. 5, 327-334.

25. KYMÄLÄINEN, H.-R., R. KUISMA, J. MÄÄTTÄ and A.-M. SJÖBERG (2009): Assessment of cleanness of environmental surfaces in cattle barns and piggeries. Agr. Food Sci. 18, 268-282.

26. MAES, D., L. PLUYM and O. PELTONIEMI (2016): Impact of group housing of pregnant sows on health. Porc. Health Manag. 2, 17.

27. MAIN, D. C. J., J. CLEGG, A. SPATZ and L. E. GREEN (2000): Repeatability of a lameness scoring system for finishing pigs. Vet. Rec. 147, 574-576.

28. MCGLONE, J. J., B. VINES, A. C. RUDINE and P. DUBOIS (2004): The physical size of gestating sows. J. Anim. Sci. 82, 2421-2427.

29. NALON, E., S. CONTE, D. MAES, F. A. M. TUYTTENS and N. DEVILLERS (2013): Assessment of lameness and claw lesions in sows. Livest. Sci. $156,10-23$.

30. O'CONNELL, M. K., P. B. LYNCH, S. BERTHOLOT, F. VERLAIT and P. G. LAWLOR (2007): Measuring changes in physical size and predicting weight of sows during gestation. Animal 1, 1335-1343.

31. OSTOVIĆ, M., S. MENČIK, A. EKERT KABALIN, G. GREGURIĆ GRAČNER, M. VUČEMILO, K. MATKOVIĆ, T. TRBOJEVIĆ VUKIČEVIĆ, J.
GRAHOVAC and Ž. PAVIČIĆ (2015): The effect of rubber flooring on displaying stereotypies in gilts. Berl. Münch. Tierärztl. Wochenschr. 128, 14-19.

32. OSTOVIĆ, M., Ž. PAVIČIĆ, A. TOFANT, A. EKERT KABALIN, S. MENČIK, D. POTOČNJAK and B. ANTUNOVIĆ (2012): Sow parity, body length, postural changes and piglet crushing. Vet. arhiv 82, 319-326.

33. PAVIČIĆ, Ž., M. OSTOVIĆ, S. MENČIK, A. EKERT KABALIN, M. VUČEMILO, K. MATKOVIĆ, B. ANTUNOVIĆ, R. PAVEŠIĆ and V. ILIESKI (2014): Postural behaviour in gilts housed on concrete and rubber slats during four seasons. Mac. Vet. Rev. 37, 157-164.

34. PAVIČIĆ, Ž., T. BALENOVIĆ, M. BALENOVIĆ, M. POPOVIĆ, K. VLAHOVIĆ, H. VALPOTIĆ and N. RUDAN-BIUK (2006): Einfluss der Haltungsart und des Mikroklimas im Abferkelstall auf die Haufigkeit der Lageveranderungen der Muttersau und auf die Ferkelverluste durch Erdrucken. Tierärztl. Umschau 61, 68-76.

35. PLUYM, L., A. VAN NUFFEL, J. DEWULF, A. COOLS, F. VANGROENWEGHE, S. VAN HOOREBEKE and D. MAES (2011): Prevalence and risk factors of claw lesions and lameness in pregnant sows in two types of group housing. Vet. Med.-Czech. 56, 101-109.

36. RUSHEN, J., A. M. DE PASSILÉ, M. A. G. VON KEYSERLINGK and D. M. WEARY (2008): The welfare of cattle. Dordrecht, Netherlands: Springer.

37. TELEZHENKO, E., L. LIDFORS and C. BERGSTEN (2007): Dairy cow preferences for soft or hard flooring when standing or walking. J. Dairy Sci. 90, 3716-3724.

38. TUYTTENS, F. A. M., F. WOUTERS, E. STRUELENS, B. SONCK and L. DUCHATEAU (2008): Synthetic lying mats may improve lying comfort of gestating sows. Appl. Anim. Behav. Sci. 114, 76-85.

39. VAN RIET, M. M. J., J. VANGEYTE, G. P. J. JANSSENS, B. AMPE, E. NALON, E. J. BOS, L. PLUYM, F. A. M. TUYTTENS, D. MAES and S. MILLET (2019): On-farm claw scoring in sows using a novel mobile device. Sensors 19, 1473.

40. ZURBRIGG, K. (2006): Sow shoulder lesions: risk factors and treatment effects on an Ontario farm. J. Anim. Sci. 84, 2509-2514. 


\section{Učinak gumene podne obloge u odjeljcima za pojedinačno držanje tijekom gravidnosti na ozljede i hromost u nazimica}

Dr. sc. Mario OSTOVIĆ, dr. med. vet., izvanredni profesor, dr. sc. Sven MENČIK, dr. med. vet., docent, dr. sc. Anamaria EKERT KABALIN, dr. med. vet., redovita profesorica, dr. sc. Dražen MATIČIĆ, dr. med. vet., akademik, dr. sc. Tajana TRBOJEVIĆ VUKIČEVIĆ, dr. med. vet., redovita profesorica, dr. sc. Kristina MATKOVIĆ, dr. med. vet., redovita profesorica, Ivana SABOLEK, dr. med. vet., asistentica, dr. sc. Dalibor POTOČNJAK, dr. med. vet., redoviti profesor, dr. sc. Željko PAVIČIĆ, dr. med. vet., redoviti profesor, Veterinarski fakultet Sveučilišta u Zagrebu, Zagreb, Hrvatska

Gumene podne obloge u svinjogojskoj proizvodnji nemaju još primjenu u praksi. Međutim, istraživanja koja su se uglavnom odnosila na ozljede, hromost i ponašanje dojnih i skupno držanih gravidnih krmača polučila su pozitivne rezultate. Prema našim saznanjima, nisu provedena istraživanja pojavnosti ozljeda i hromosti u krmača ili nazimica koje su tijekom gravidnosti držane pojedinačno, $\mathrm{u}$ odjeljcima s gumenom podnom oblogom. Ovo istraživanje provedeno je $u$ pripustilištu komercijalne svinjogojske farme tijekom 28-dnevnog proizvodnog ciklusa u svim godišnjim dobima. Svaki ciklus obuhvatio je 28 nazimica podijeljenih u dvije jednake skupine, kontrolnu i pokusnu. Nazimice kontrolne skupine bile su u standardnim odjeljcima za pojedinačno držanje tijekom gravidnosti, $\mathrm{s}$ betonskim rešetkastim podom, koji je $\mathrm{u}$ pokusnoj skupini nazimica bio prekriven

prilagođenom gumenom podnom oblogom Ozljede su se procjenjivale 1., 8., 15. i 28. dana svakog ciklusa, a hromost 1 . dana pojedinog ciklusa i prilikom premještanja nazimica iz pripustilišta (29. dan). U nazimica pokusne skupine utvrđeno je značajno manje $(P<0,05)$ ozljeda u hladnijem razdoblju, dok obloge nisu imale utjecaja na hromost nazimica ni $\mathrm{u}$ jednom godišnjem dobu. Nisu ustvrđene značajne povezanosti između ozljeda i udjela nazimica s određenim stupnjem hromosti. Može se zaključiti da gumene podne obloge poboljšavaju dobrobit nazimica držanih u pojedinačnim odjeljcima tijekom gravidnosti, kroz manju učestalost ozljeda; međutim, pri njihovoj primjeni trebaju se uzeti $u$ obzir ambijentalne temperature.

Ključne riječi: svinje, gumena obloga, pod, ozljede, hromost, dobrobit životinja 